\title{
INFLUENCE OF THE MOTIVATIONAL COMPONENT OF THE PHYSICAL EDUCATION ON THE STUDENTS' TRAINING SYSTEM
}

DOI: $10.24234 /$ se.2021.3.1.264

\author{
AUTHOR'S DATA: \\ Yuriy Dolynniy, PhD, Associate Professor \\ Chair of Physical Education and Sports \\ Donbas State Machine-Building Academy, Ukraine \\ Contacts: mr.dya69@gmail.com
}

\begin{abstract}
The purpose of the study is to find out the influence of the motivational component on the training system of physical education students who plan to use health-saving technologies in their professional activities in the physical education of schoolchildren who, for health reasons, belong to special medical groups.

Professional education of future specialists in physical education and sports in higher education institutions requires technological changes in physical culture and health work with children and youth, who belong to special medical groups due to their state of health. The solution of this direction of training of future specialists in physical education and sports will be more effective if the motivational component of training is applied in the educational process of students. Studies apply the motivational component of learning. Research determines that the use of a motivational component in the training program for future physical education professionals has a much better effect on the learning process of students, mastering the curriculum, self-development, and self-improvement both in higher education and in future professional activities.
\end{abstract}

Keywords: specialists, physical education, motivation, research, health-preserving technologies, schoolchildren, special medical group.

\section{INTRODUCTION}

At the stage of development of modern society, rapid progress, computerization, and modernization of all spheres of human life, less and less attention is paid to physical activity. This 
is especially true for children and young people who spend all their time studying, computers and gadgets. Children spend less and less time on the street, they have almost completely stopped playing outdoor and sports games (Dolinnyj, 2016a; Haivolia, 2007).

This attitude of young people to exercise leads to detrimental health consequences. Children are getting increasingly sick, lose their immunity. Frequent illnesses lead to chronic illnesses and later can even result in disability. In addition, rapid technological progress often leads to injury in people, and this often leads to disability. Therefore, today in the world, the most relevant physical culture and recreational activities, both for healthy people and for people with weakened health and disabilities. Namely, social, physical, psychological, and educational activities that provide an opportunity for children and young people with impaired health, to get as close as possible to a full-fledged social life in the school environment, which in the future will ensure such children's active participation in the main spheres of society.

In connection with the above, in the modern school environment, a significant number of schoolchildren are attributed for health reasons to a special medical group. The preservation of the psychophysical health of children is one of the primary educational tasks, which is emphasized by the Concept of general secondary education. The use of health-saving technologies in the psychophysical education of schoolchildren of special medical groups is an important component in the system of teaching methods for students of physical culture (Prykhoda, 2007; Deminska, 2004).

To solve this direction of state policy, highly qualified specialists in the field of physical education and sports who are trained to work with such a contingent of people are needed, who are able to develop and conduct physical culture and recreational activities, apply health-saving technologies, physical therapy and occupational therapy to people with impaired health or disabilities.

\section{LITERATURE REVIEW}

Many researchers have paid special attention to the physical education of various segments of the population in their research papers. The scientific interest for our research is the experience of physical culture and health work of foreign researchers (Bouchard, Shephard, \& Stephens, 1994). 
In recent years, the socio-pedagogical problem of training future specialists in physical education and sports has been studied in the dissertations of Sushchenko (2016) where the author was reflecting theoretical and methodological principles of professional training of future specialists in physical education and sports in higher education. The other authors in their scientific paper highlighted the importance of theoretical and practical professional training of future specialists in physical education and sports while using information technology (Aghazadeh \& Kyei, 2009). Bowker (2006) has shown the relationship between sports participation and selfesteem during early adolescence and described the theoretical and methodological principles of professional training of future fitness trainers in higher education.

However, the problem of professional training, namely the professional competence of future specialists in physical education and sports was not the subject of a separate study during the reform of higher education (Bashkin,2006).

\section{METHODOLOGY}

The survey was conducted on the basis of quantitative and qualitative research to collect research data. For a quantitative study, the testing method was used (Shuster\& Wade, 2003).

Testing is one of the most common methods in sociology. With this method, quantitative and qualitative indicators can be obtained that contribute to the detection of a research problem. Distinguish between standardized and projective testing methods. Standardized tests have been used as a data collection method during quantitative research because they can be used to quantify (Orzhekhovska, 2011; Popov, 2006).

To process the results of the obtained data, the methods of mathematical statistics were used. Suslakov, Ivanov, Tyurin, Kramer, and others provide the quantitative and qualitative analysis (Shuster \& Wade, 2003).

The data were processed using the statistical package of the computer program Microsoft Excel 8.0 for Windows. The assessment of statistical hypotheses was based on a 5\% level of significance, which provides the necessary accuracy in pedagogical research (Bielikova, 2012; Pieshkova, 2007). 


\section{Participants and ethics}

Implementation of the practical component of the system of professional training of specialists in physical education and sports for the health of preserved technologies with students who belong to special medical groups in terms of health was carried out in 12 institutions of higher education in Ukraine. To determine the dynamics of mastering the experimental and general curriculum for future bachelors in physical education and sports were involved 232 students from $2^{\text {nd }}$ to $4^{\text {th }}$ year (2014-15 academic year, 2015-16 academic year, 2016-17 academic year).

Taking into account the fact that at present there is no research ethics committee in Ukraine that has received an official ethical license to conduct research, the plan and topic of the experiment has been agreed upon with the scientific department of the higher educational institution and is carried out in accordance with the state budget research work of the Department of Physical Education and sports.

The educational process in the experimental groups was organized with the introduction of the "Program for training specialists in physical education and sports for the use of health-saving technologies with students who belong to a special medical group in terms of health". Differences in the study groups depended on the conditions, presented in the general program of training of specialists in this field of training. Classes on the experimental "Program of training specialists in physical education and sports for the use of health-saving technologies with students who belong to a special medical group in terms of health" in the study groups were conducted according to the working curriculum of the experimental program in the amount of 24 hours per week.

\section{Data collection}

In order to objectively conduct an experiment on the impact of the motivational criterion of training future specialists in physical education and sports to apply health-saving technologies with students who belong to a special medical group in terms of health, a questionnaire was developed: a study of motivational criterion aimed at identifying educational and cognitive motivation of students (future specialists in physical education and sports) while studying in higher educational institutions of Ukraine. 


\section{Data analysis}

The data were collected using standardized questionnaires. This made it possible to determine the impact of the implementation of the experimental "Program for training specialists in physical education and sports for the use of health-saving technologies with students who belong to a special medical group in terms of health".

Analysis of the results of the questionnaire study of the motivational criterion of readiness aimed at identifying educational and cognitive motivation of future professionals in physical education and sports to apply health-saving technologies with students who are in a special medical group during training from 2014 to 2017 year in higher educational institutions of Ukraine made it possible to identify the largest increase in the arithmetic mean differences of high, medium, sufficient and low levels of evaluation of control and experimental groups:

- after the first control test (500 classes): 2.5 times in CG and EG the largest increase in arithmetic mean differences at a sufficient level; 3.5 times in CG the largest increase in arithmetic mean differences at a high level; 2 times in EG the largest increase in arithmetic mean differences at a high level;

- after the second control test (1000 classes): 1.5 times in CG and EG the largest increase in arithmetic mean differences at the average level; 3.0 times in CG the largest increase in arithmetic mean differences at a low level;

- after the third control test (1500 lessons): 1.75 times in EG the largest increase in arithmetic mean differences at a high level; 1.5 times in CG the largest increase in arithmetic mean differences at a low level;

- after the fourth control test (2000 lessons): 1.75 times in EG the largest increase in arithmetic mean differences at a high level $[5 ; 6]$.

\section{FINDINGS}

Based on the obtained indicators of growth of the motivational criterion of readiness, we can conclude that the research of experimental and general programs. The analysis of the study shows that there is a significant improvement in educational performance when applying the motivational criterion in the experimental program training of specialists in physical education and sports for the application of health-saving technologies with students who belong to a special 
medical group due to their state of health. That is, the effectiveness of the impact of the implemented experimental program is largely determined by rational methods and educational content of the proposed program and working curriculum in the process of training future professionals in physical education and sports.

\section{DISCUSSION}

The purpose of this study is to find out the impact motivational criterion for the training of specialists in physical education and sports for the use of health-saving technologies with students who belong to a special medical group due to their state of health.

This research is based on the idea the implementation of the practical component of the system of professional training of specialists in physical education and sports for the use of healthsaving technologies with students who belong to a special medical group due to their health will be more effective if the motivational aspect of the activity is included in the student training program.

The students of the control groups studied in accordance with the general education program for the training of specialists in physical education and sports of the higher education institution. The experiment was based on generally accepted principles and methods of teaching. To determine the dynamics of mastering the experimental and general curriculum for future bachelors in physical education and sports from 2 to 4 years (2014-15 academic year, 2015-16 n.r., 2016-17 n.r.) was taken from the working curriculum the average number of hours for 3 years of study in the amount of 2000 hours at the rate of 22.5 hours per week, taking into account 89 weeks of study for 3 years. Determining the dynamics of mastering the experimental and general curriculum for future bachelors during the experiment was evaluated at 4 control points for the entire period of experimental work (from 2014 to 2017). The first control point from 0 to 500 training hours; the second checkpoint from 500 to 1000 teaching hours; the third from 1000 to 1500 study hours; fourth from 1500 to 2000 study hours. Analysis of the dynamics of indicators

of the impact of experimental development and general curriculum for the level of education of bachelors was conducted every 500 classes based on the results of questions (\%) of the ratio of motivational, cognitive, the readiness of future specialists in physical education and sports to use 
health-saving technologies with students who are in good health belongs to a special medical group (Dolinnyj, 2016a, b).

\section{IMPLICATIONS FOR PRACTICE AND FUTURE RESEARCH}

Vocational education of future specialists in physical education and sports in higher education institutions requires technological changes in physical culture and health aimed at working with children who belong to a special medical group due to their state of health. Healthpreserving technologies, as well as a large number of children with impaired health on the planet, need highly qualified physical education professionals who are able to successfully implement developmental, educational, and health programs for the improvement and development of children and youth. Modern authors offer different solutions to this area of training future specialists in physical education and sports for the application of health-preserving technologies with schoolchildren. But the use of the motivational component of student learning has a positive effect on the assimilation of educational material and attracts future professionals to the systematic professional development and improvement of their professional knowledge and professional level.

\section{CONCLUSION}

This study examines the influence of the motivational component on vocational training specialists in physical education and sports to the use of health-saving technologies with students who belong to a special medical group due to their state of health. The research results emphasize the importance of this area of training future specialists. The main limitation of the study is the relatively small number of respondents who took part in the experiment.

As a result of our research, we have identified the most influential curriculum. At the beginning of the pedagogical experiment, students differed little in terms of educational readiness ( $\mathrm{P}<0.05)$. Training sessions were held in parallel in experimental groups according to the experimental program of training specialists in physical education and sports to the application of health-saving technologies with students who, due to their state of health, belong to a special 
medical group and in control groups in accordance with the schedule of regular work curricula of a higher education institution in an average of 22.5 hours for a week.

\section{REFERENCE LIST}

1. Aghazadeh, S.M., \& Kyei, K. (2009). A Quantitative Assessment of Factors Affecting College Sports’ Team Unity. College Student Journal, 43(2), 294-302.

2. Bashkin, I. (2006). Rol i mistse fizychnoi reabilitatsii u zahalnii systemi okhorony zdorovia naselennia / I. Bashkin, E. Makarova, A. Kavakze Rizik // Teoriia i metodyka fizychnoho vykhovannia i sportu. - № 3. - S. 25 - 29.

3. Bielikova, N., O. (2012). Teoretychni i metodychni zasady pidhotovky maibutnikh fakhivtsiv z fizychnoi reabilitatsii do zdoroviazberezhuvalnoi diialnosti - Dysertatsiia doktora ped. nauk: 13.00.04, Kabinet Ministriv Ukrainy, Nats. Un-t bioresursiv i pryrodokorystuvannia Ukrainy. - K. - $450 \mathrm{~s}$.

4. Bouchard, C., Shephard, R., J., \& Stephens T. (1994). Physical activity, fitness, and health: International proceedings and consensus statement. Champaign, IL: Human Kinetics.

5. Bowker, A. (2006). The Relationship between Sports Participation and Self-Esteem during Early Adolescence. Canadian Journal of Behavioural Science, 38(3), 214-229. doi: $10.1037 /$ cjbs2006009.

6. Deminska, L., O. (2004). Mezhpredmetni zviazky u protsesi profesiinoi pidhotovky maibutnikh uchyteliv fizychnoi kultury; dys. ... kand. ped. nauk: 13.00.04 / Deminska Larysa Oleksiivna. - Donetsk. - 208 s.

7. Dolinnyj, Yr., A. (2016a). Kriterii uspishnosti profesijnoyi gotovnosti majbutn`ogo faxivcya $\mathrm{z}$ fizychnogo vyxovannya do reabilitacijnoyi roboty $\mathrm{z}$ ditmy $\mathrm{z}$ obmezhenymy fizichnymy mozhlyvostamy /Yr. A. Dolinnyj //Gluxivski naukovi chytannia. Aktualni pytannya suspilny`x ta gumanitarnyx nauk / Materialy VI Mizhnarodnoyi internetkonferenciyi molodyx uchenyx i studentiv 27 - 29 veresnya 2016 roku. - Gluxiv: RVV Gluxivs`kogo NPU im. O. Dovzhenka. - S. 54-58.

8. Dolinnyj, Yr., A. (2016b). Suchasni teoretychni osnovy pidgotovky majbutnix faxivciv z fizychnogo vyxovannya i sportu do reabilitacijnoyi roboty/Yr.A. Dolinnyj// Pedagogyka i sovremtnnyi aspekty fizicheskogo vospitanya: zb. nauk. pracz` II Mizhnar. nauk.-prakt. 
konf., (21-22 kvitnya2016roku) / za zag. red. Yr.A. Dolinnogo. - Kramatorsk: DDMA. - S. 235-241.

9. Haivolia, R., Yu. (2007). Do pytannia profesiinoi pidhotovky maibutnikh fakhivtsiv fizychnoho vykhovannia /R. Yu. Haivolia // Molodizhnyi naukovyi visnyk: Fizychne vykhovannia i sport: zb. nauk. pr. / Volyn. nats. un-t im. Lesi Ukrainky. - Lutsk. -S. 3-7.

10. Orzhekhovska, V., M. (2011). Zdoroviazberezhuvalne navchannia i vykhovannia: problemy, poshuk /V. M. Orzhekhovska // Naukovi zapysky NDU im. M. Hoholia: Psykholoho-pedahohichni nauky. - № 4. - S. 29-31.

11. Pieshkova, O., V. (2007). Vstup do spetsialnosti (Fizychna reabilitatsiia): [navchalnyi posibnyk] /O.V. Pieshkova. - Kharkiv. - 147 s.

12. Popov, S., N. (2006). Fizicheskaya reabilitatsiya /S. N. Popov. - Rostov n/D.: Feniks. - 608 s.

13. Prykhoda, I., V. (2007). Orhanizatsiino-metodolohichni pidkhody do profesiinoi pidhotovky fakhivtsiv z fizychnoi reabilitatsii v Ukraini /I. V. Prykhoda // Problemy suchasnoi pedahohichnoi osvity. - Vyp. 15, Ch. 1. - S. 60 - 66.

14. Sushchenko, A., D. (2016). Realizaciya studentami potrebnostey v dopolnotelnikh uslugakh w sosremennikh usliviyakh: dissertaciq na soiskanie uchenoy stepeni kandidata socilogicheskih nauk: 22.00.04 / A. D. Sushchenko; [mesto zashiti: Uralskiy federalniy universitet im. Pervogo prezidenta Rossii B.N. Elcina]. -Ekaterinburg, 2016. - 170 s. Bibliograf.: s. 150-170 (181 nazv.).

15. Shuster, S., M.\&Wade, M. (2003). Mating Systems and Strategies, Princeton University Press, DOI: $10.2307 /$ j.ctvs32sqk. 